DOI https://doi.org/10.15589/znp2021.2(485).3

УДК 629.463.001.63

\title{
DETERMINATION OF THE LOAD OF THE OPEN WAGONS FRAME WITH A CLOSED RIDGE BEAM
}

\section{ВИЗНАЧЕННЯ НАВАНТАЖЕНОСТІ РАМИ НАПІВВАГОНА ІЗ ЗАМКНЕНОЮ КОНСТРУКЦІЄЮ ХРЕБТОВОЇ БАЛКИ}

\author{
Alyona L. Lovska ${ }^{1}$ \\ alyonaLovskaya.vagons@gmail.com \\ ORCID: 0000-0002-8604-1764 \\ Oleksij V. Fomin ${ }^{2}$ \\ fomin1985@ukr.net \\ ORCID: 0000-0003-2387-9946
}

Andrij V. Rybin ${ }^{1}$

rybinandrey2006@gmail.com

ORCID: 0000-0003-4430-8018

\author{
А. О. Ловська ${ }^{1}$, \\ докт. техн. наук, доцент \\ О. В. Фомін ${ }^{2}$, \\ докт. техн. наук, професор \\ А. В. Рибін ${ }^{1}$,
старший викладач
}

${ }^{1}$ Ukrainian State University of Railway Transport, Kharkiv

Украйнський державний університет залізничного транспорту, м. Харків

${ }^{2}$ State University of Infrastructure and Technologies, Kyiv

Державний університет інфраструктури та технологій, м. Київ

\begin{abstract}
The dynamic load and strength of the open wagon frame with the closed structure of the ridge beam under the main operating load conditions were determined.

Purpose. The aim of the study is to illuminate the characteristics of the determination of the load of the open wagon frame with the closed structure of the ridge beam in operating conditions.

Method. The longitudinal load of the half-wagon with the closed structure of the ridge beam was determined. The solution of differential equations of motion is implemented by the Runge-Kutt method in the software complex MathCad . The acceleration obtained is taken into account when calculating the strength of the open wagon frame. The method of finite elements implemented in the program complex SolidWorks Simulation is used as a calculation. The design life of the open wagon frame is calculated.

Results. The accelerations acting on the load-bearing structure of the open wagon with a closed ridge beam are determined. The resulting acceleration value is found to be within the standard values. The main indicators of the strength of the open wagon frame are calculated. The maximum equivalent voltages were $328 \mathrm{MPa}$ and occur during a manoeuvre collision. It is established that the design life of the open wagon frame does not exceed 32 years.

Scientific novelty. The mathematical model of the dynamic load of the open wagon during a shunting impact has been further developed. The model produces acceleration as a component of the dynamic load that affects the open wagon. A model of the strength of the frame of the open wagon with the closed structure of the ridge beam is created. This model makes it possible to determine the main indicators of the strength of the open wagon frame under operating loading conditions.

Practical importance. The research carried out will help to ensure the strength of the heavy-duty open wagon structures, to reduce maintenance costs and to create the appropriate design for innovative freight wagon designs.

Key words: transport mechanics; open wagon; supporting structure; open wagon frame; ridge beam; dynamic load; strength.

Анотація. У статті проведено визначення динамічної навантаженості та міцності рами напіввагона $з$ замкненою конструкцією хребтової балки при основних експлуатаційних режимах навантаження.

Мета. Метою дослідження є висвітлення особливостей визначення навантаженості рами напіввагона з замкненою конструкцією хребтової балки при експлуатаційних режимах.

Методика. Проведено визначення повздовжньої навантаженості напіввагона з замкненою конструкцією хребтової балки. Розв'язок диференціальних рівнянь руху здійснений за методом Рунге-Кутта в програмному комплексі MathCad. Отримана величина прискорення врахована при розрахунках на міцність рами напіввагона.
\end{abstract}




\section{ПРИКЛАДНА МЕХАНІКА №2-2021}

Як розрахунковий використано метод скінчених елементів, реалізований в програмному комплексі SolidWorks Simulation. Розраховано проєктний строк служби рами напіввагона.

Результати. Визначено прискорення, яке діє на несучу конструкцію напіввагона $з$ замкненою хребтовою балкою. Встановлено, що отримана величина прискорення не перевищує нормативного значення. Розраховано основні показники міцності рами напіввагона. Максимальні значення еквівалентних напружень склали 328 МПа, вони виникають при маневровому співударянні. Встановлено, що проєктний строк служби рами напіввагона складає не менше 32 років.

Наукова новизна. Доопрацьовано математичну модель динамічної навантаженості напіввагона при маневровому співударянні. Модель дозволяє отримати прискорення як складову частину динамічного навантаження, що діє на напіввагон. Створено модель міцності рами напіввагона з замкненою конструкцією хребтової балки. Дана модель дозволяє визначити основні показники міцності рами напіввагона при експлуатаційних режимах навантаження.

Практична значимість. Проведені дослідження сприятимуть забезпеченню міцності несучих конструкцій напіввагонів при експлуатаційних режимах навантаження, скороченню витрат на їх утримання, а також створенню відповідних напрацювань щодо проєктування інноваційних конструкцій вантажних вагонів.

Ключові слова: транспортна механіка; напіввагон; несуча конструкція; рама напіввагона; хребтова балка; динамічна навантаженість; міцність.

\section{ПОСТАНОВКА ЗАДАЧІ}

Розвиток транспортної логістики є невід'ємною складовою частиною успішного функціонування економіки країни. Відомо, що привальований об’єм перевезень вантажів від загального вантажообігу багатьох країн припадає на залізничний транспорт. Для утримання лідерських позицій залізничної галузі в спектрі вантажоперевезень важливим $\epsilon$ забезпечення iї високоефективним рухомим складом з покращеними техніко-економічними показниками. Досягти цього можливо шляхом урахування та впровадження на стадії проєктування рухомого складу в умовах вагонобудівних підприємств нетривіальних інноваційних рішень, спрямованих на підвищення ефективності його роботи. Особлива увага при цьому повинна приділятися несучим конструкціям рухомого складу, оскільки вони піддаються дії значних знакозмінних навантажень в експлуатації. Це викликає їх пошкодження, необхідність здійснення позапланових видів ремонту, виділення додаткових коштів на утримання рухомого складу в експлуатації для забезпечення своєчасної доставки вантажів тощо.

3 огляду на це актуальним є проведення досліджень щодо удосконалення, а також оптимізації несучих конструкцій рухомого складу для забезпечення ефективності його функціонування та розвитку економіки країни.

\section{АНАЛІЗ ОСТАННІХ ДОСЛІДЖЕНЬ І ПУБЛІКАЦІЙ}

Висвітлення особливостей модернізації несучих конструкцій вантажних вагонів наведено у роботі [1]. Запропоновані заходи спрямовані на подовження строку експлуатації вагонів. Ще одним напрямом роботи $є$ удосконалення системи діагностики технічного стану модернізованих несучих конструкцій вагонів.

У роботі [2] розглянуто структурно-динамічний аналіз вантажного вагона. Як розрахунковий використано метод скінчених елементів. Дослідження були проведені щодо багаторівневої системи вільності вагона.

Важливо сказати, що в даних роботах не приділено уваги питанням зменшення оптимізації несучих конструкцій вагонів з метою їх матеріалоємності.

Дослідження міцності кузова напіввагона в умовах експлуатаційних навантажень проводиться у роботі [3]. Як прототип був обраний напіввагон моделі С80В побудови КНР. Результати дослідження показали, що метод прогнозування втомної міцності кузова, заснований на гібридному моделюванні динаміки та аналізі за методом скінчених елементів, $\epsilon$ можливим.

У роботі [4] наведені результати теоретичного та експериментального дослідження міцності вантажного вагона. При цьому до уваги прийняті нормативні величини навантажень, які діють на вагон з боку рейкових колій під час експлуатації.

Однак в зазначених роботах не приділено уваги питанням удосконалення найбільш навантажених елементів вагонів для забезпечення їх міцності в експлуатації.

Висвітлення стратегічних задач вагонобудівників у розвитку важковагового руху проводиться у роботі [5]. Розглянуто можливі варіанти збільшення вантажопідйомності рухомого складу, погонного навантаження, зниження тари. При цьому в роботі не обговорюються можливі заходи щодо зниження навантаженості несучих конструкцій вагонів в експлуатації.

Конструкційні особливості інноваційного рухомого складу побудови «Уралвагонзавода» для колії 1520 мм розглянуті у публікації [6]. Тут висвітлено заходи щодо модернізації рухомого складу та його складових частин для підвищення ефективності роботи.

Однак в конструкціях розглянутих типів вагонів не передбачено складових елементів, які б сприяли покращенню міцнісних характеристик в умовах найбільш несприятливих режимів. 
Заходи щодо удосконалення несучої конструкції вагона наведені у роботі [7]. Як розрахунковий був використаний метод ОПК. Конструктивна схема кузова, що проєктується, дозволила знизити масу вагона і підвищити його вантажопідйомність із забезпеченням необхідної міцності і надійності конструкції. Однак дослідження були проведені стосовно вагонахопера. При цьому не було приділено уваги удосконаленню несучої конструкції напіввагона як одного 3 найбільш поширених типів вагонів в експлуатації.

Питання оптимізації несучих конструкцій вантажних вагонів висвітлюється у роботах [8; 9]. 3 метою зменшення матеріалоємності вагона запропоновано використання у якості його несучих елементів труб круглого перерізу. Однак реалізація цієї ідеї викликає складнощі на етапі виготовлення та технічного обслуговування вагона під час експлуатації.

\section{ВІДОКРЕМЛЕННЯ НЕ ВИРІШЕНИХ} РАНІШЕ ЧАСТИН ЗАГАЛЬНОЇ ПРОБЛЕМИ

Аналіз літературних джерел [1-9] дозволяє зробити висновок, що для підвищення ефективності експлуатації напіввагонів актуальним питанням є проведення досліджень щодо удосконалення їх несучих конструкцій. При цьому важливим $є$ визначення можливості зменшення матеріалоємності несучих конструкцій напіввагонів при забезпеченні умов міцності. Це сприятиме не тільки скороченню витрат на утримання напіввагонів, а і створенню відповідних напрацювань щодо проєктування їх інноваційних конструкцій, розвитку наукових засад, спрямованих на зниження матеріалоємності напіввагонів, підвищенню вантажопідйомності, збільшенню середніх швидкостей руху в завантаженому та порожньому станах, зменшенню загальної виробничої та експлуатаційної собівартості.

\section{МЕТА ДОСЛІДЖЕННЯ}

Метою дослідження $є$ висвітлення особливостей визначення навантаженості рами напіввагона 3 замкненою конструкцією хребтової балки при експлуатаційних режимах. Для досягнення зазначеної мети були визначені такі завдання:

- визначити динамічну навантаженість рами напіввагона;

- визначити основні показники міцності рами напіввагона;

- розрахувати проєктний строк служби рами напіввагона.

\section{МЕТОДИ, ОБ'СКТ ТА ПРЕДМЕТ ДОСЛІДЖЕННЯ}

При проведенні досліджень були використані такі методи: метод оптимізації за резервами міцності - при визначенні оптимальних параметрів перерізу хребтової балки; метод Лагранжа II роду - при доопрацюванні математичної моделі навантаженості несучої конструкції напіввагона; метод Рунге-Кутта - при розв'язанні диференціальних рівнянь руху напіввагона; метод скінчених елементів - при визначенні основних показників міцності рами напіввагона; метод визначення проєктного строку служби - при визначенні проєктного строку служби рами напіввагона.

Об’єкт дослідження - процес навантаження несучої конструкції напіввагона при експлуатаційних режимах.

Предмет дослідження - несуча конструкція напіввагона.

\section{ОСНОВНИЙ МАТЕРІАЛ}

Для забезпечення міцності рами напіввагона запропоновано удосконалення конструкції хребтової балки. При цьому замість типових профілів, які використовуються у рамі напіввагона, запропоновано використання спеціалізованого профілю (рис. 1). Даний профіль має швелероподібну конфігурацію, але його полки дещо збільшені за довжиною. Таке рішення дозволяє створити замкнений переріз хребтової балки.

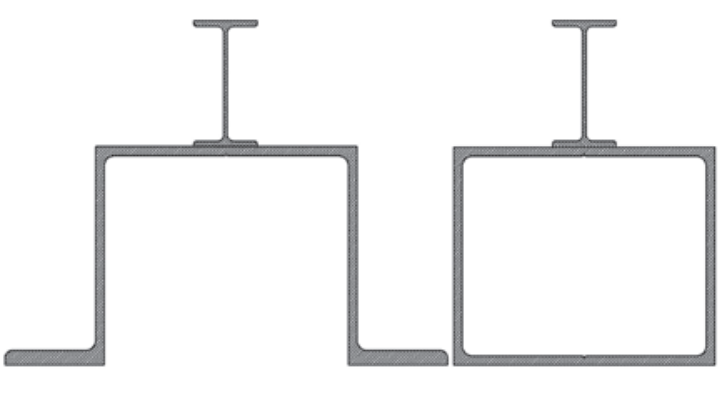

a)

б)

Рис. 1. Переріз хребтової балки

а) типова конструкиія; б) удосконалена конструкиія

При цьому визначення оптимальних параметрів перерізу хребтової балки здійснено за резервом міцності типової конструкції [8]. Встановлено, що під час використання спеціалізованого профілю хребтової балки забезпечується зниження маси рами майже на 4\% порівняно з типовою конструкцією (табл. 1).

Для визначення навантаженості напіввагона 3 урахуванням удосконаленої конструкції хребтової балки проведено математичне моделювання. Для цього використано математичну модель, сформовану Інститутом технічної механіки [10]. Важливо сказати, що зазначена модель створена для визначення навантаженості довгобазної конструкції вагона-платформи, завантаженого контейнерами-цистернами. 3 огляду на це в рамках даного дослідження модель було доопрацьовано.

$$
\begin{gathered}
M_{б p} \cdot \ddot{x}+\left(M_{B} \cdot h\right) \cdot \ddot{\varphi}=P_{n}-2 P_{m p}, \\
I_{B} \cdot \ddot{\varphi}+\left(M_{B} \cdot h\right) \cdot \ddot{x}-g \cdot \varphi \cdot\left(M_{B} \cdot h\right)= \\
=l \cdot F_{T P}\left(\operatorname{sign} \dot{\Delta}_{1}-\operatorname{sign} \dot{\Delta}_{2}\right)+l\left(k_{1} \cdot \Delta_{1}-k_{2} \cdot \Delta_{2}\right),
\end{gathered}
$$


ПРИКЛАДНА МЕХАНІКА №2-2021

Таблиця 1. Параметри перерізів хребтової балки напіввагона

\begin{tabular}{|c|c|c|c|c|c|c|c|}
\hline Елемент рами & Maca 1 м, кг & Довжина, м & $\sigma_{\text {екв }}$, МПа & $W_{x}, \mathbf{c M}^{3}$ & $W_{y}, \mathbf{c M}^{3}$ & $\begin{array}{c}{\left[W_{x}\right],} \\
\mathbf{c m}^{3}\end{array}$ & $\begin{array}{c}{\left[W_{y}\right],} \\
\mathbf{c M}^{3}\end{array}$ \\
\hline Балка хребтова (типова) & 154,05 & 12,8 & 312,4 & 1317,95 & 2566,7 & 1186,1 & 2310,03 \\
\hline $\begin{array}{l}\text { Балка хребтова } \\
\text { (удосконалена) }\end{array}$ & 148,43 & 12,8 & 298,6 & 1822,85 & 2578,54 & 1571,42 & 2222,88 \\
\hline
\end{tabular}

$$
M_{B} \cdot \ddot{z}=k_{1} \cdot \Delta_{1}+K_{2} \cdot \Delta_{2}-F_{T P}\left(\operatorname{sign} \dot{\Delta}_{1}-\operatorname{sigh} \dot{\Delta}_{2}\right),
$$

де

$$
\Delta_{1}=z-l \cdot \varphi ; \Delta_{2}=z+l \cdot \varphi,
$$

$M_{б p}-$ маса брутто вагона; $M_{B}-$ маса несучої конструкції вагона; $I_{B}-$ момент інерції вагона; $P_{n}-$ величина повздовжньої сили на задній упор автозчепу; $P_{m p}-$ сили тертя, які виникають між п'ятниками рами та підп'ятниками візків; I - половина бази вагона; $\mathrm{F}_{T P}$ - абсолютне значення сили сухого тертя у ресорному комплекті; $k_{1}, k_{2}$ - жорсткість пружин ресорного підвішування візків вагона; $\mathbf{X}, \varphi, \mathrm{Z}$ - координати, що відповідають, відповідно, повздовжньому, кутовому навколо поперечної осі та вертикальному переміщенню вагона.

Також у цій формулі враховано силу тертя, яка виникає між п'ятниками та підп'ятниками, та зумовлена дією повздовжньої сили на задній упор автозчепу. Значення повздовжньої сили, яка діє на задній упор автозчепу, прийнято рівним $3,5 \mathrm{MH}[11 ; 12]$. Розв'язок математичної моделі здійснений за методом Рунге-Кутта в програмному комплексі MathCad. Стартові умови покладені рівними нулю. Розрахунок здійснений стосовно напіввагона моделі 12-757 побудови ПАТ «КВБЗ».

Результати розрахунку показали, що максимальне прискорення, яке діє на несучу конструкцію напіввагона, складає 38,4 м/с ${ }^{2}$ (рис. 2). Важливо сказати, що отримана величина прискорення не перевищує нормативних значень $[11 ; 12]$.

Отримана величина прискорення врахована при розрахунках на міцність рами напіввагона як основного несучого елемента кузова. Просторову модель рами створено в програмному комплексі SolidWorks (рис. 3). Розрахунок на міцність рами здійснений в програмному комплексі SolidWorks Simulation.

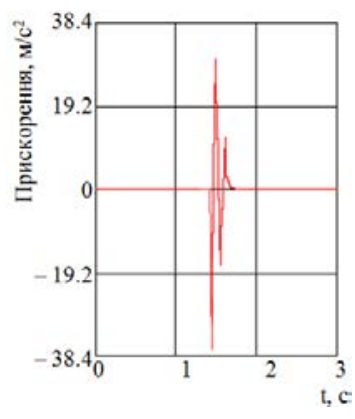

Рис. 2. Прискорення несучої конструкції напіввагона

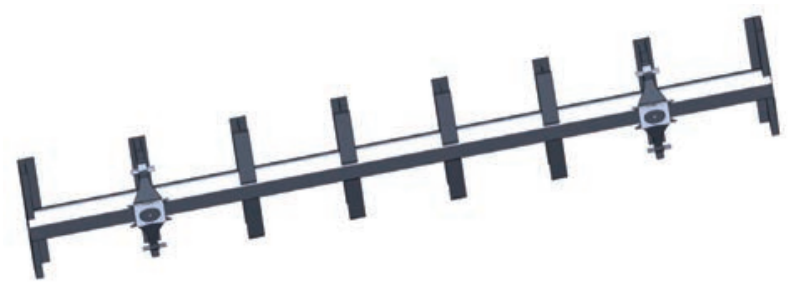

Рис. 3. Просторова модель рами напіввагона

При складанні скінчено-елементної моделі рами напіввагона були застосовані ізопараметричні тетраедри. Оптимальну кількість скінчених елементів визначено за графоаналітичним методом [13; 14]. Кількість елементів сітки склала 81813 , вузлів - 27 261. Максимальний розмір елементу сітки дорівнює 188,0 мм, мінімальний - 38,0 мм, максимальне співвідношення боків елементів 1015,4 , відсоток елементів з співвідношенням боків менше трьох - 8,59, більше десяти - 41. Мінімальна кількість елементів в колі -8 , співвідношення збільшення розміру елементу - 1,6. Матеріал конструкції - сталь марки 09Г2С зі значенням межі міцності 490 МПа та межі плинності 345 МПа. В якості допустимих напружень враховано напруження плинності $[11 ; 12]$.

Розрахункова схема рами напіввагона наведена на рис. 4. При складанні моделі враховано, що на неї діє вертикальне статичне навантаження $P_{6}^{c m}$, повздовжнє навантаження на задній упор автозчепу $P_{y d}$, а також горизонтальні реакції $P_{2}$ в п'ятниках, зумовлені дією навантаження $P_{y \partial}$ (рис. 5).

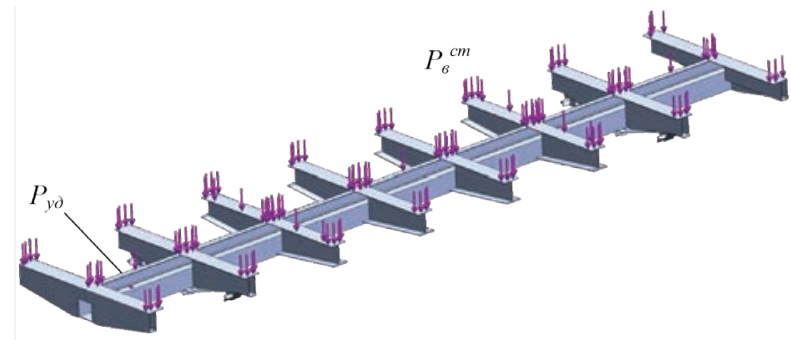

Рис. 4. Розрахункова схема рами напіввагона

Результати розрахунку наведені на рис. 6 та 7 . Встановлено, що максимальні еквівалентні напруження зосереджені в зоні взаємодії хребтової балки 3 шворневою та складають 328 МПа (рис. 6). 


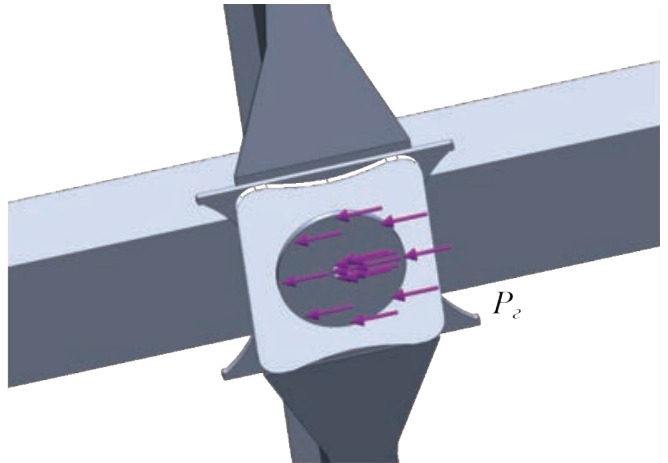

Рис. 5. Схема прикладення горизонтального навантаження на п'ятник
Максимальні переміщення були зафіксовані в середній частині рами напіввагона та склали 8,5 мм (рис. 7).

Проведені розрахунки дозволяють зробити висновок, що міцність рами напіввагона забезпечується. При цьому максимальні еквівалентні напруження на $5 \%$ нижчі за допустимі $[11 ; 12]$. Найбільш навантажені зони рами наведені на рис. 8. Це зони взаємодії хребтової балки зі шворневими.

Розрахунок здійснений і стосовно інших режимів навантажень вагона в експлуатації. Результати розрахунку наведені в табл. 2.

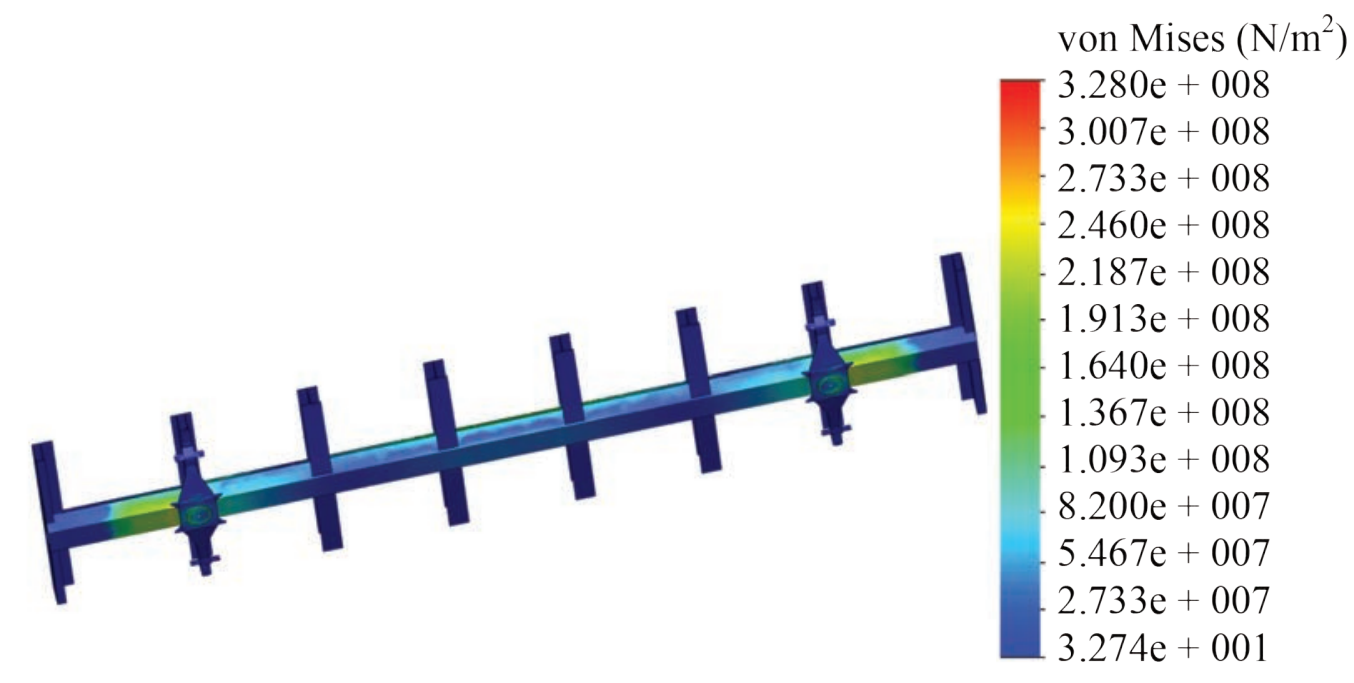

Рис. 6. Напружений стан рами напіввагона

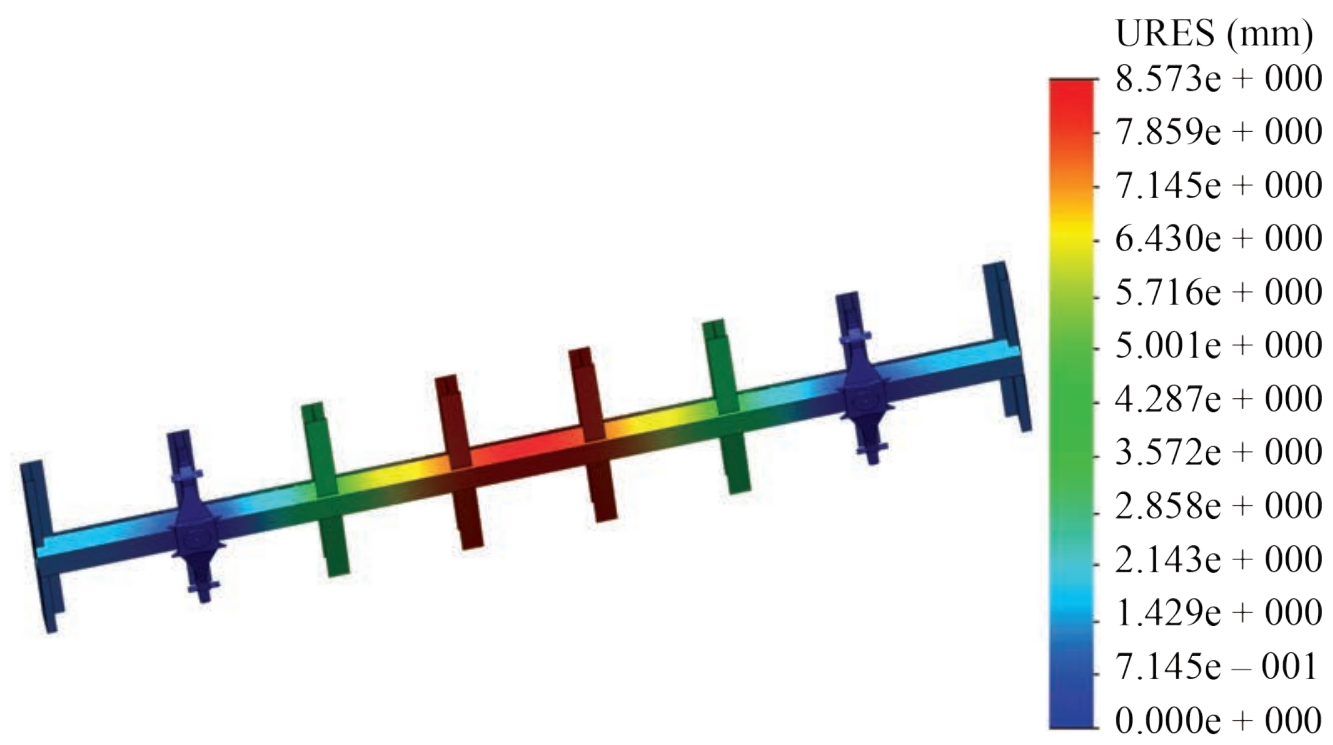

Рис. 7. Переміщення в вузлах рами напіввагона 


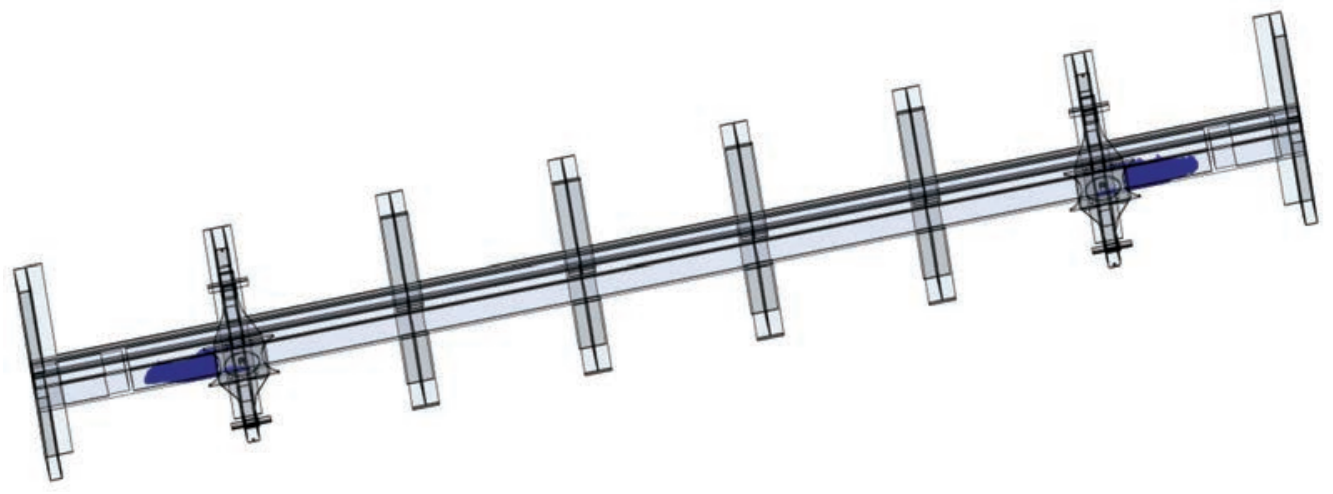

Рис. 8. Найбільш навантажені зони рами напіввагона

Таблиця 2. Основні показники міцності рами напіввагона

\begin{tabular}{|c|c|c|c|c|c|}
\hline \multirow{2}{*}{ Показник міцності } & \multicolumn{5}{|c|}{ Режим навантаження } \\
\cline { 2 - 6 } & \multicolumn{4}{|c|}{ І режим } & \multicolumn{2}{c|}{ III режим } \\
\cline { 2 - 6 } & удар & стиснення & ривок-розтягнення & удар-стиснення & ривок-розтягнення \\
\hline Напруження, МПа & 328,0 & 316,6 & 305,4 & 297,6 & 284,1 \\
\hline Переміщення в вузлах, мм & 8,5 & 8,1 & 7,8 & 7,8 & 7,7 \\
\hline
\end{tabular}

За даними, наведеними у табл. 2, можна зробити висновок, що міцність рами напіввагона при основних експлуатаційних режимах забезпечується.

3 метою визначення проєктного строку служби рами напіввагона використано методику професора П.А. Устіча [15]:

$$
T_{n}=\frac{\left(\sigma_{-1 д} /[n]\right)^{m} \cdot N_{0}}{B \cdot f_{e} \cdot \sigma_{c в}\left(k_{\partial в}+\psi_{\sigma} / K_{\sigma}\right)^{m}},
$$

де $\sigma_{-1 д}-$ середнє значення границі витривалості; $\mathrm{n}$ - допустимий коефіцієнт запасу міцності; $m$ - показник ступеня кривої втоми; $N_{0}$ - база випробувань; $B-$ коефіцієнт, який характеризує час безперервної роботи об'єкту в секундах; $f_{b}$ - ефективна частота динамічних напружень; $\sigma_{c \varepsilon}-$ напруження від статичного вагового навантаження; $k_{\partial в}-$ коефіцієнт вертикальної динаміки; $\psi_{\sigma}-$ коефіцієнт чутливості; $\mathrm{K}_{\sigma}-$ загальний коефіцієнт зниження втомної міцності.

При розрахунках прийнято такі вхідні параметри: $\sigma_{-1 д}=245$ МПа; $\mathrm{n}=2 ; m=8 ; N_{0}=10^{7} ; B=3,07 \cdot 10^{6}$ сек ; $f_{\varepsilon}=2,7 \Gamma ц ; k_{\partial \varepsilon}=0,35 ; \psi_{\sigma} / \mathrm{K}_{\sigma}=0,2$.

Результати проведених розрахунків встановили, що проєктний строк служби рами напіввагона становить не менше 32 років.

Важливо зазначити, що отримана величина проєктного строку служби повинна бути уточнена з урахуванням додаткових досліджень вертикальної навантаженості рами напіввагона.

\section{ОБГОВОРЕННЯ ОТРИМАНИХ РЕЗУЛЬТАТІВ}

Проведено визначення навантаженості рами напіввагона 3 замкненою конструкцією хребтової балки. Особливістю рами є те, що вона складається 3 двох швелероподібних профілів, полки яких дещо збільшені за довжиною. Таке рішення дозволяє створити замкнений переріз хребтової балки, при цьому забезпечується зниження маси рами майже на $4 \%$ порівняно $з$ типовою конструкцією.

Проведено визначення динамічної навантаженості несучої конструкції напіввагона. Встановлено, що максимальне прискорення, яке діє на несучу конструкцію напіввагона, становить 38,4 м/ $\mathrm{c}^{2}$ (рис. 2). Важливо сказати, що обмеженням математичної моделі $є$ те, що вона враховує переміщення вагона в плоскій системі координат.

Визначено основні показники міцності рами напіввагона. Розрахунок був здійснений за методом скінчених елементів. Результати розрахунку показали, що максимальні еквівалентні напруження в рамі не перевищують допустимі (рис. 6). Розраховано проєктний строк служби рами. Він становить не менше 32 років.

Перспективним напрямом в рамках даного дослідження є визначення вертикальної навантаженості несучої конструкції напіввагона. Також важливим $€$ проведення експериментальних досліджень щодо визначення міцності несучої конструкції напіввагона.

\section{ВИСНОВКИ}

1. Визначено динамічну навантаженість рами напіввагона з замкненою конструкцією хребтової балки. Розрахунок був здійснений стосовно напіввагона моделі 12-757 побудови ПАТ «КВБЗ». Результати розрахунку показали, що максимальне прискорення, 
яке діє на несучу конструкцію напіввагона, становить 38,4 м/с 2 . Отримана величина прискорення не перевищує нормативних значень.

2. Визначено основні показники міцності рами напіввагона. Розрахунок був здійснений за методом скінчених елементів. Максимальні еквівалентні напруження зосереджені в зоні взаємодії хребтової балки 3 шворневою та складають 328 МПа. Максимальні переміщення зафіксовані в середній частині рами напіввагона та дорівнюють 8,5 мм. Проведені розрахунки дозволяють зробити висновок, що міц- ність рами напіввагона забезпечується, при цьому максимальні еквівалентні напруження на 5\% нижчі за допустимі.

3. Розраховано проєктний строк служби рами напіввагона. Встановлено, що проєктний строк служби становить не менше 32 років.

Проведені дослідження сприятимуть забезпеченню міцності несучих конструкцій напіввагонів в експлуатації, скороченню витрат на їх утримання та створенню відповідних напрацювань щодо проєктування інноваційних конструкцій вантажних вагонів.

\section{REFERENCES}

[1] Płaczek M., Wróbel A., Buchacz A. (2016). A concept of technology for freight wagons modernization. IOP Conf. Series: Materials Science and Engineering, Vol. 161. doi:10.1088/1757-899X/161/1/012107.

[2] Haraka S. S., Sharma S. C., Harsha S. P.. (2014). Structural dynamic analysis of freight railway wagon using finite element method. Procedia Materials Science. Vol. 6, P. 1891-1898.

[3] Yuan Y. Q., Li Q., Ran K. (2012). Analysis of C80B Wagons Load-Stress Transfer Relation. Applied Mechanics and Materials. Vol. 148-149. P. 331-335.

[4] Yoon S. C. (2010). Evaluation of Structural Strength in Body Structure of Freight Car. Key Engineering Materials. Vol. 417418. P.181 - 184 .

[5] Boronenko Yu. P. (2013). Strategicheskie zadachi vagonostroitelej v razvitii tyazhelovesnogo dvizheniya. Transport Rossijskoj Federacii. №5(48). S. 68 - 73.

[6] (2010). Innovacionnyj podvizhnoj sostav proizvodstva «Uralvagonzavoda» dlya zheleznyh dorog «prostranstva $1520 \mathrm{~mm}$. Transport Rossijskoj Federacii. №3(28). S. 20 - 21.

[7] Kebal Yu. V., Shatov V. A., T'okotev O. M., Murashova N. G. (2017). Udoskonalennya konstrukciï vagona-hopera dlya perevezennya zerna. Zbirnik naukovih prac DETUT. Seriya «Transportni sistemi i tekhnologiï». Vip. 30. S. 113 - 122.

[8] Fomin O. V., Lovska A. O. (2015). Doslidzhennya docil'nosti zastosuvannya kruglih trub v yakosti elementiv nesuchih sistem zaliznichnih vagoniv-platform. Visnik Skhidnoukrains'kogo nacional'nogo universitetu imeni V. Dalya. № 1(218). S. $38-45$.

[9] Fomin O., Lovska A., Masliyev V., Tsymbaliuk A., Burlutski O. (2019). Determining strength indicators for the bearing structure of a covered wagon's body made from round pipes when transported by a railroad ferry. Eastern-European Journal of Enterprise Technologies. № 1/7 (97). P. 33 - 40.

[10] Bogomaz G. I., Mekhov D. D., Pilipchenko O. P., Chernomashenceva Yu. G. (1992). Nagruzhennost kontejnerov-cistern, raspolozhennyh na zheleznodorozhnoj platforme, pri udarah v avtoscepku. Zb. nauk. prac "Dinamika ta keruvannya ruhom mekhanichnih sistem”. S. 87 - 95.

[11] Vagoni vantazhni. Zagalni vimogi do rozrahunkiv ta proektuvannya novih i modernizovanih vagoniv koliyi $1520 \mathrm{~mm}$ (nesamohidnih). (2015). DSTU 7598:2014.

[12] Vagonyi gruzovyie. Trebovaniya k prochnosti i dinamicheskim kachestvam. (2014). GOST 33211-2014.

[13] Vatulia G., Komagorova S., Pavliuchenkov M. (2018). Optimization of the truss beam. Verification of the calculation results. MATEC Web of Conferences. Vol. 230, 02037. doi: 10.1051/matecconf $/ 201823002037$

[14] Vatulia G., Lobiak A., Chernogil V., Novikova M. (2019). Simulation of performance of cfst elements containing differentiated profile tubes filled with reinforced concrete. Materials Science Forum. Vol. 968. P. 281 - 287.

[15] Ustich P. A., Karpych V. A., Ovechnikov M. N. (1999). Nadezhnost relsovogo netyagovogo podvizhnogo sostava. Moskva.

\section{СПИСОК ВИКОРИСТАНОЇ ЛІТЕРАТУРИ}

[1] Płaczek M., Wróbel A., Buchacz A. (2016). A concept of technology for freight wagons modernization. IOP Conf. Series: Materials Science and Engineering, Vol. 161. DOI:10.1088/1757-899X/161/1/012107.

[2] Haraka S.S., Sharma S.C., Harsha S.P. (2014). Structural dynamic analysis of freight railway wagon using finite element method. Procedia Materials Science. Vol. 6, P. 1891-1898.

[3] Yuan Y. Q., Li Q., Ran K. (2012). Analysis of C80B Wagons Load-Stress Transfer Relation. Applied Mechanics and Materials. Vol. 148-149. P. 331-335.

[4] Yoon S.C. (2010). Evaluation of Structural Strength in Body Structure of Freight Car. Key Engineering Materials. Vol. 417-418. P. 181-184.

[5] Бороненко Ю.П. (2013). Стратегические задачи вагоностроителей в развитии тяжеловесного движения. Tpaнсnорm Российской Федерации. № 5 (48). С. 68-73.

[6] Инновационный подвижной состав производства «Уралвагонзавода» для железных дорог. Транспорт Российской Федеращии. 2010. № 3 (28). С. 20-21. 


\section{ПРИКЛАДНА МЕХАНІКА №2-2021}

[7] Кебал Ю.В., Шатов В.А., Тьокотєв О.М., Мурашова Н.Г. (2017). Удосконалення конструкції вагона-хопера для перевезення зерна. Збірник наукових праџь ДЕТУТ. Серія «Транспортні системи і технологї̈. Вип. 30. С. 113-122.

[8] Фомін О.В., Ловська А.О. (2015). Дослідження доцільності застосування круглих труб в якості елементів несучих систем залізничних вагонів-платформ. Вісник Східноукраӥнського національного університету імені В. Даля. № 1 (218). C. 38-45.

[9] Fomin O., Lovska A., Masliyev V., Tsymbaliuk A., Burlutski O. (2019). Determining strength indicators for the bearing structure of a covered wagon's body made from round pipes when transported by a railroad ferry. Eastern-European Journal of Enterprise Technologies. № 1/7 (97). P. 33-40.

[10] Богомаз Г.И., Мехов Д.Д., Пилипченко О.П., Черномашенцева Ю.Г. (1992). Нагруженность контейнеров-цистерн, расположенных на железнодорожной платформе, при ударах в автосцепку. Зб. наук. Праць «Динаміка та керування рухом механічних систем». С. 87-95.

[11] Вагони вантажні. Загальні вимоги до розрахунків та проєктування нових і модернізованих вагонів колії 1520 мм (несамохідних). (2015). ДСТУ 7598:2014.

[12] Вагоны грузовые. Требования к прочности и динамическим качествам. (2016). ГОСТ 33211-2014.

[13] Vatulia G., Komagorova S., Pavliuchenkov M. (2018). Optimization of the truss beam. Verification of the calculation results. MATEC Web of Conferences. Vol. 230, 02037. DOI: 10.1051/matecconf/201823002037.

[14] Vatulia G., Lobiak A., Chernogil V., Novikova M. (2019). Simulation of performance of cfst elements containing differentiated profile tubes filled with reinforced concrete. Materials Science Forum. Vol. 968. P. 281-287.

[15] Устич П.А., Карпыч В.А., Овечников М.Н. Надежность рельсового нетягового подвижного состава. Москва, 1999.

(C) Ловська А. О., Фомін О. В., Рибін А. В. Дата надходження статті до редакції: 11.06.2021 Дата затвердження статті до друку: 28.06.2021 